\title{
Premature Deagriculturalisation? Land Inequality and Rural Dependency in Limpopo Province, South Africa
}

\author{
ROBERT EASTWOOD, JOHANN KIRSTEN, \& MICHAEL \\ LIPTON
}

\section{Introduction}

Economic development is normally associated with a declining share of agriculture in both workforce and output. After confirming this for a cross-section of developing and transitional countries, we establish a strong negative association, controlling for GNP/capita, between land inequality and agriculture's workforce share (Section II). High land inequality, originating from enforced land transfers in early development, is linked to abnormally low agricultural workforce shares, given GNP/capita, in Latin America, FSU countries, and Southern Africa.

If such workforce deagriculturalisation arises early in development, alternative employment-based livelihoods are likely to be insufficient to sustain rural populations. Rural dependency, defined as heavy dependence on transfers from outside the rural area, accompanied by high unemployment, is one plausible outcome. Others include mass emigration (nineteenth century Ireland), concentration in urban favelas, and low-income rural stagnation with 'distress diversification'. Since all these outcomes appear undesirable, and involve agricultural shrinkage before other productive sectors can adequately absorb the shed farm labour, we call such cases 'premature deagriculturalisation'.

To explore the processes, we must go beyond international cross-sections. Section III uses a South African survey (Kirsten et al., 2002) in a former 'homeland' area of Limpopo Province where deagriculturalisation has indeed led to rural dependency. ${ }^{1}$ This outcome has been favoured by universal pension rights and a high-employment, even if capital-intensive, mining sector, so that many rural households survive by 'specialising' in receiving migrant remittances or pensions. But is there a prima facie link between rural dependency and land inequality? In Limpopo Province, the estimated land Gini is 0.93 (Appendix), higher than almost any estimate worldwide (IFAD, 2001: 117-19). ${ }^{2}$ The Limpopo survey was part of a comparative study, ${ }^{3}$ so we compare some Limpopo results with analogous data from Rajasthan, India (Sagar, 2002), with less extreme land inequality and no evidence of rural dependency. In rural Rajasthan, 83 per cent of income is local (i.e., factor income of residents); in Limpopo, only 44 per cent. Own-farm income accounts for almost all the difference. Limpopo income depends heavily on remittances and pensions, and to a lesser extent on rural civil service salaries; unemployment is very high. The rural non-farm (RNF) sector in Limpopo is not taking up the slack in employment or income.

Much of rural Asia experienced transition from heavy dependence on farm income to 'mature' deagriculturalisation, as prior growth of labour-intensive small-scale farming stimulated labour-intensive RNF growth ${ }^{4}$ through forward, backward and consumption linkages (Mellor, 1976). This connection is 
supported by many micro-studies (Bell et al., 1982; Hazell and Roell, 1983; Harriss, 1987; Hazell and Ramasamy, 1991) and by national studies of rural industrialization in China (Byrd et al., 1990) and 'proto-industrialisation' in fifteenth century Flanders and elsewhere (Kriedte et al., 1981; Ogilvie et al., 1996). Yet deagriculturalisation in the Limpopo survey area has brought, not other local income, but widespread household dependency on transfer payments alongside high adult unemployment, especially in the sub-regions with least widely distributed farmland. This suggests that the reduced agricultural workforce share was premature - as was its main cause, separation of most rural households from significant control over land, leading to labour displacement by big, capital-intensive farms.

In providing survey evidence on possible effects of deagriculturalisation in South Africa, we say little about the processes causing extreme land inequality and labour extrusion. Sometimes deagriculturalisation is a harbinger of development (Bryceson and Jamal, 1997), but there may be less benign explanations connected to human agency. Colonial land grab is the most obvious candidate. The literature on 'deagrarianisation' and 'depeasantisation' argues that they were 'sparked by 'turning point' policies in South Africa during the late 19th and early 20th centuries' (Bryceson, 2000: 1-2). ${ }^{5}$ As in Latin America and the FSU, so in South Africa: it was mainly political land seizures, not labour flight to new non-farm opportunities, that led to displacement of smallholders by large farms. Most black farmers were forced off their land, which was subsequently farmed in large holdings by whites, well before new industrial employment became available. White farm expansion, sometimes 'led' by wars of conquest, fuelled this process well before the 1913 Land Act, which confined over 85 per cent of farmland to whites. Subsequent expulsions of rural Africans, often into 'dumping grounds' offering unattractive farming prospects, continued until the 1980s. Some of the extruded labour was absorbed in mining, and from the 1940s in industry; until the 1940s, indeed, policies of forcing blacks off the land (leading to larger and more capital-intensive farms) were defended on grounds of 'labour shortage'. However, from the 1960s clear 'labour surplus' emerged. Population growth, continued forced removals of blacks from their farms, and rising displacement of labour by capital on white farms outweighed new off-farm prospects, leading to large and rising unemployment (now around 30 per cent). Little land redistribution has occurred since the end of apartheid in 1994. We defer discussion of current land policy to the concluding section of the paper.

\section{Land Distribution, GNP Per Head and Agricultural Salience: The International Evidence}

In this section we use cross-national regressions to investigate the following hypotheses:

(i) The share of agriculture in GDP is inversely related to GNP per capita.

(ii) The share of agriculture in total workforce is inversely related to GNP per capita.

(iii) High land inequality depresses the output share of agriculture.

(iv) High land inequality depresses the workforce share of agriculture. 
What theory and micro evidence might generate such regularities? (i) and (ii) can arise in either a standard 262 Heckscher-Ohlin model or a two-good specificfactors model (Krugman and Obstfeld, 2003: chapter 3), with countries identical in either case except for exogenous differences in factor endowments. In the specific-factors framework, with manufactures produced by capital and labour and food by land and labour, it must be cross-country variations in capital per head rather than land per head that matter (otherwise land-rich countries will have both high GNP/head and high output and workforce shares in agriculture). ${ }^{6}$

(iii) and (iv) do not arise in a constant-returns-to-scale, perfect-competition world. There, farm size is indeterminate and variations in its distribution have no effect. In particular, the distribution of owned land has no impact on the distribution of operated land. However, we know that (a) farm size varies a great deal within countries; and (b) factor productivities vary systematically with it e.g., the 'inverse relationship' (Heltberg, 1998). A good theory should explain both (a) and (b). While land heterogeneity is, and non-constant technical returns to scale may be, important, the literature emphasises transactions costs in factor and output markets. For such costs to explain both (a) and (b), imperfections in two markets are needed. ${ }^{7}$ Eswaran and Kotwal (1986) assume perfect rental markets in labour and land but household-specific capital endowments (including owned land) together with convex supervision costs for non-family labour, and then show how agriculture will differentiate into four classes according to capital endowments. Richer households operate larger farms with lower labour-land ratios. Historical evidence (Binswanger et al., 1995) supports such a causal link from owned land inequality to operated land inequality.

How does land inequality affect agricultural employment and output? The aggregate labour-land ratio equals the weighted sum of labour-land ratios for different farm sizes, the weights being the shares of total land in each size class. A labour-land ratio falling with farm size does not guarantee that an equalising land redistribution raises total employment, since the shares of total land at both ends of the distribution may be reduced (Appendix). For any given equalising redistribution, the more sharply the labour-land ratio falls with farm size, the more likely is total farm employment to rise; and the more sharply the outputland ratio falls with farm size, the more likely is total farm output to rise.

In developing countries, with increasing farm size the labour-land ratio falls sharply. In Pakistan in 1972, it fell from 9.15 workers/hectare on farms below 0.4 ha to 0.12 workers/hectare on farms above 60.7 ha; data for Bangladesh, Thailand, Indonesia and India were comparable. Simulations showed that egalitarian redistribution would raise labour demand and use by 19-24 per cent in Bangladesh, Pakistan, Thailand and the Outer Islands of Indonesia, though by only 8.6 per cent in Java (Booth and Sundrum, 1984: 100-9, 279-80). A plausible model of partial land redistribution on Brazil's estate sub-sector raised person-year equivalents of labour use in agriculture from 2.6 to 3.0 million over the 1978 base case (Kutcher and Scandizzo, 1981: 201). This confirms Berry and Cline (1979: 58): labour use 'could be expected to rise as the result of measures that redistributed land from the large-farm sector into smaller family farms'. World Bank evidence from the 1970s showed 'employment per hectare higher . . . in those countries that have . . . more equal distribution of land ownership' (ibid.: 37). Analogously, land productivity falls as farm size rises, ${ }^{8}$ although part of this fall reflects exogenously higher land quality on smaller 
farms. ${ }^{9}$

So greater land inequality is associated with lower output and lower employment in agriculture. The latter clearly implies a lower share of workforce there. For output, however, greater farm size inequality might affect nonagricultural output, complicating any conclusion about the effect on the agricultural output share. Very unequal farmland might well, by stimulating capital-intensity in farming and thus attracting capital into agriculture, reduce capital available to support non-farm output, making the effect on the agricultural output share of GDP indeterminate. ${ }^{10}$

Our hypotheses, and the discussion above, have emphasised the effects of land inequality, ignoring mean farm size. That would be justifiable for a single country, assuming that redistribution would not change the total number of holdings, but across countries we cannot use that reasoning. We therefore test whether the land Gini drives out farm size as an explanatory variable. It does (see below), but why? Large mean farm size is found in countries with greater land abundance, which as such normally increases farm workforce and output; yet given land abundance larger farm size, e.g., due to land clearances, reduces workforce and output per hectare. Our econometric findings may indicate that these offsetting effects on agriculture's share in total workforce and output are approximately in balance.

Table 1 shows the cross-country regressions relating workforce and GDP shares of agriculture to GNP/head and land inequality (regressions containing grossly insignificant regressors are not reported). ${ }^{11}$ Land inequality is measured by the farmland Gini coefficient where available (49 countries), but we also try dummy variables for Latin America, the former Soviet bloc, and South Africa, where past policies to shift agriculture into large farms have led to high inequality and the use of capital-intensive production methods. Note the caveat that our results are

Table 1. National output and workforce shares in agriculture

\begin{tabular}{lcccc}
\hline $\begin{array}{l}\text { Regression no. } \\
\text { Dep. Var: }\end{array}$ & 1 & \multicolumn{1}{c}{2} & 3 & 4 \\
Ag share of & GDP & Workforce & Workforce & Workforce \\
\hline LnGNP/cap & -11.98 & -21.87 & -16.23 & -20.90 \\
& $(-12.13)^{\star \star \star}$ & $(-11.43)^{\star \star \star}$ & $(-6.10)^{\star \star \star}$ & $(-9.59)^{\star \star \star}$ \\
Landgini & & -48.18 & & -42.90 \\
Sadum & -3.81 & $(-6.65)^{\star \star \star}$ & -24.07 & $(-4.68)^{\star \star \star}$ \\
Ladum & $(-4.18)^{\star \star *}$ & & $(-4.57)^{\star \star \star}$ & \\
Ladum & & & -19.24 & -4.61 \\
TRANSdum & & & $(-4.12)^{\star \star \star}$ & $(-0.94)$ \\
Nobs & 105 & & -26.20 & \\
R-squared & 0.65 & 49 & $(-5.99)^{\star \star \star}$ & 49 \\
\hline
\end{tabular}


Notes: (1) All equations estimated by weighted OLS using square roots of workforce as weights; t-statistics in brackets. (2) All equations pass Ramsey RESET test, using the second, third and fourth powers of the dependent variable, at 5 per cent significance. (3) Heteroscedasticity corrected S.E.s in Equations 1 and 3 only, on the basis of the Cook- Weisberg test. (4) ${ }^{* * *}$ sig 1 per cent.

potentially vulnerable to unobserved heterogeneity. If country-specific factors that affect agriculture's shares in workforce and GDP are correlated with our included regressors, the estimated coefficients are biased.

Equation 1 shows that a 10 per cent rise in GNP per capita is associated with a fall in the agricultural output share of 1.2 per cent of GDP, supporting Hypothesis (i). However, neither the Gini coefficient of operated land, nor the Latin American or Transitional dummies, have any impact: Hypothesis (iii) is not supported. ${ }^{12}$ South Africa is a significant outlier (see the dummy in Equation 1); the fitted share of agriculture in GDP for SA is 7.1 per cent, compared with the actual share of 3.3 per cent.

On the share of agriculture in workforce, Equations 2 and 3 support Hypotheses (ii) and (iv). In Equation 2, a rise of 10 per cent in GNP/capita lowers agriculture's workforce share by 2.2 percentage points, and a 1 percentage point rise in the Gini of operated land lowers it by 0.48 percentage points. Equation 3 uses blunt instruments - dummy variables - instead of the land Gini, allowing the inclusion of many more countries, and this reduces the estimated GNP/capita effect by about a quarter; there are large effects from our land inequality proxies - 19-27 per cent for the Latin American and Transitional groupings, and for South Africa. Lacking land Ginis for the last two, we can compare the dummy variable and land Gini explanations only for Latin America. Equation 4 shows conclusively that land inequality, rather than 'Latin Americanness', accounts for the low agricultural workforce shares there. The weighted mean of the land Gini for the 17 Latin American countries in our sample is 0.83 , compared with 0.51 in the other 31 countries, ${ }^{13}$ so the estimated average effect of land inequality in Latin American countries, using Equation 2, is to lower the agricultural workforce share by 14.7 per cent (the dummy variable regression suggests a somewhat larger effect). When mean farm size is added to the equations, it is everywhere insignificant. This is perhaps not surprising, as discussed above. However, the land Gini and mean farm size are highly (nonlinearly) correlated - the sample rank correlation is 0.71 - so to some extent the superior statistical performance of the Gini may be an artifact of the linearity of our estimating equations.

\section{An Analytical Anatomy of Rural African Livelihoods in Limpopo Province}

The cross-country evidence suggests a strong association between unequal land and the employment share in agriculture, given GNP per head. This does not imply that 'deagriculturalisation' has even occurred in any given case, still less that it has been 'premature'. High land inequality could theoretically arise from the spread of large settler ranches into empty land, but, in practice, self-serving 'terra nullius' interpretations of history have been found wanting. ${ }^{14}$ The apartheid era in South Africa provides an extreme example of forced concentration of land 
and other non-labour agricultural resources in large farms with low labour-land ratios. Our case study of livelihoods in one of the affected areas aims to shed light on whether deagriculturalisation in this case was premature.

\section{The Household Sample and the Survey Area}

This 1999-2000 survey is confined to African households in the former Lebowa homeland areas of Limpopo Province. Twenty-four villages in seven arid or semi-arid provincial sub-districts (see map) were randomly selected from the 1996 census list of villages. 585 randomly selected households were interviewed, ${ }^{15}$ containing 4,338 persons, 5.2 per cent of the villages' population. The villages are largely isolated and remote, with low levels of development. Despite lacking basic infrastructure (good roads, electricity, water), most villages have experienced some improvement since 1996 through targeted government investment.

For some purposes, we cluster the sub-districts into three 'regions': West, South and Central. ${ }^{16}$

- 'West' (sub-districts Mokerong and Phalala) comprises areas west of the provincial capital, Polokwane (Pietersburg). African-farmed and whitefarmed areas alike are relatively dry, with extensive livestock production the dominant farming activity, although some dryland maize and other crops are produced, in white farms under borehole irrigation. White-owned farms include game and beef ranches and large-scale potato, vegetable and citrus producers. A typical white commercial farm neighbouring Phalala or Mokerong employs 100-200 full time workers, generating substantial African employment.

- 'Central' (sub-districts Seshego and Bochum) villages enjoy effective transport links with Polokwane; many household members work (and spend) there or in Pretoria, 2.5 hours by road. Farming is mainly a residual activity, with some livestock and limited cropping.

- 'South' (sub-districts Zebediela, Schoonoord and Praktiseer) villages are the most remote, located deep in ex-homelands, far from white-owned farms. Farming features variable dryland maize and sorghum production with limited livestock. Zebediela, however, also has a large citrus estate and some small-scale irrigated vegetable production.

\section{Incomes, Assets and Unemployment at All-Sample Level}

Here we show that Limpopo, alongside high land inequality, ${ }^{17}$ has a profile of rural African livelihoods characterised by low average shares, in total income, of agricultural income, and indeed of local income as a whole. The latter implies dependence on external (i.e., non-local) incomes in the form of pensions and remittances. We use data from a parallel survey in dryland areas of Rajasthan (Sagar, 2002) to illustrate a more typical profile, with roughly similar agroecology to Limpopo, somewhat lower income and higher poverty - but much more widespread access to farmland and water. In both surveys, three village clusters were selected, with contrasting rainfall in the range $35-55 \mathrm{~cm}$, in each case with a marked rainy season. 
Table 2 gives income and asset statistics, disaggregated by poverty and landholding status, for the Limpopo and Rajasthan surveys. ${ }^{18}$ The disparity in the shares of income from different sources is striking. We divide income into wages, farm income, pensions and remittances, treating the first two of these as income from 'local' factors and the other two from 'external' factors; we later subdivide wages by sector. In rural Rajasthan, ${ }^{19} 83$ per cent of income is local (so pensions and remittances play, on average, a minor role); in Limpopo, ${ }^{20}$ only 43 per cent of income is local. The big difference is in own-farm income: 38 per cent in Rajasthan and only 4 per cent in Limpopo. Agricultural wages ${ }^{21}$ account for a further 3 per cent in Rajasthan and 4 per cent in Limpopo, so local agriculture accounts for 41 per cent and 8 per cent of income respectively, though the low Limpopo figure hides sharp regional differences (Section III(iv)). Further, the similar shares of wages, and of non-agricultural wages, ${ }^{22}$ conceal an important difference between the RNF sectors. In Rajasthan, of the 45 per cent of income from wages, none derives from civil service employment; in Limpopo the wages share is 39 per cent, over a third of which (14 per cent of all income) is so derived. This suggests that the relative insignificance of (former homeland) agriculture in Limpopo is accompanied by relative weakness in the RNF sector. This is confirmed by greater RNF activity in the less 'deagriculturalised' West region.

The minor role in livelihoods of own-farm output is underscored for Limpopo by a comparison of landless and landed households. ${ }^{23}$ Though an estimated 43 per cent of Limpopo households are landless, these average no less income than the landed. ${ }^{24}$ In Rajasthan, where only 7 per cent of households are landless, they average 37 per cent less income than the landed. The small economic role of own-account farmland for African households in Limpopo is emphasised by their comparatively low share of wealth held in the form of land (Table 2$).{ }^{25}$ It is not that these households are without land area: the 43 per cent with land average 2.9 ha (93 per cent and 1.7 ha in Rajasthan) and distribution among landed households is reasonably even (Gini $1 / 40.35$ ), but this dryland has low productive capacity, being largely unirrigated. With rainfall scanty and unreliable, purchased farm inputs (which are widely available) are seen by Limpopo smallholders as too costly or risky, given credit costs and constraints; for many decades, land, rural power, irrigation, credit and research were heavily steered towards large farms - much more so than in Rajasthan, where smallholders purchased many farm inputs, including appropriate improved seeds and irrigation.

Though landedness within this former 'homelands' area does not increase average income, it might reduce poverty risk (for instance, landedness might reduce income variance). To assess this, we use a poverty line comparable to that used for Rajasthan. ${ }^{26}$ It happens to identify about 20 per cent of the Limpopo households as income-poor. Landed households have higher estimated poverty than landless ones (23 per cent vs. 16 per cent, $p=0.11$ ); a finer disaggregation of households by land size suggests no significant association with poverty risk either way, in contrast to the strong negative relationship shown in several other developing countries (Ravallion and Sen, 1994; IFAD, 2001:76). ${ }^{27}$ To sum up: land distribution within this former African homeland taken as a whole does not appear, on its own, to explain variation in household income or poverty risk. This fits in with the low share of own-farm income in household income. 
Table 2. Assets, income, landedness and poverty: whole sample

\begin{tabular}{|c|c|c|c|c|c|c|c|c|c|c|c|c|c|c|c|}
\hline & hhinc & aeqinc & $\begin{array}{c}\text { wages } \\
\% \text { of } \\
\text { hhinc }\end{array}$ & $\begin{array}{c}\mathrm{o} / \mathrm{w} \\
\text { civser* }\end{array}$ & $\begin{array}{c}\text { pens } \\
\% \text { of } \\
\text { hhinc }\end{array}$ & $\begin{array}{c}\text { farm } \\
\% \text { of } \\
\text { hhin } \\
c\end{array}$ & $\begin{array}{l}\text { remit } \\
\% \text { of } \\
\text { hhinc }\end{array}$ & hhwea & aeqwea & $\begin{array}{c}\text { land } \\
\% \text { of } \\
\text { wealth }\end{array}$ & $\begin{array}{c}\text { smallstock } \\
\% \text { of } \\
\text { wealth }\end{array}$ & $\begin{array}{c}\text { largestock } \\
\% \text { of } \\
\text { wealth }\end{array}$ & $\begin{array}{c}\text { dwellings } \\
\% \text { of } \\
\text { wealth }\end{array}$ & $\begin{array}{c}\text { hhassts } \\
\% \text { of } \\
\text { wealth }\end{array}$ & $\begin{array}{c}\text { fmassts } \\
\% \text { of } \\
\text { wealth }\end{array}$ \\
\hline \multicolumn{16}{|l|}{ Limpopo } \\
\hline Total & 19,504 & 5,487 & 39.1 & (14.5) & 17.8 & 4.3 & 38.8 & 53,902 & 15,214 & 4.6 & 3.3 & 11.0 & 63.8 & 13.8 & 3.4 \\
\hline Landed $(57 \%)$ & 19.572 & 5,287 & 30.8 & & 20.9 & 6.8 & 41.6 & 61,842 & 16,276 & 7.0 & 4.3 & 16.0 & 56.6 & 10.8 & 5.2 \\
\hline Landless (43\%) & 19,454 & 5,753 & 50.2 & & 13.7 & 1.0 & 35.2 & 43,318 & 13,799 & 0.0 & 1.5 & 1.6 & 77.6 & 19.3 & 0.0 \\
\hline Non-poor $(80 \%)$ & 23,263 & 6,641 & 39.2 & & 16.5 & 3.9 & 40.5 & 58,601 & 17,092 & 4.0 & 3.1 & 12.2 & 62.0 & 14.7 & 3.9 \\
\hline Poor $(20 \%)$ & 4,672 & 935 & 37.8 & & 42.9 & 12.4 & 6.8 & 35,360 & 7,805 & 8.5 & 4.6 & 3.3 & 75.8 & 7.7 & 0.1 \\
\hline \multicolumn{16}{|l|}{ Rajasthan } \\
\hline Total & 42,792 & 11,083 & 44.8 & $(0.0)$ & 4.0 & 38.4 & 12.8 & 300,200 & 77,724 & 64.2 & 3.3 & 2.1 & 25.4 & 1.3 & 3.7 \\
\hline Landed (93\%) & 43,903 & 11,234 & 43.7 & & 3.7 & 39.8 & 12.8 & 318,678 & 82,251 & 64.9 & 3.3 & 2.1 & 24.8 & 1.3 & 3.7 \\
\hline Landless (7\%) & 27,525 & 9,004 & 67.9 & & 10.0 & 9.0 & 13.1 & 46,181 & 15,491 & 0.0 & 9.1 & 4.2 & 83.1 & 2.9 & 0.8 \\
\hline Non-poor (71\%) & 54,456 & 14,064 & 45.7 & & 4.3 & 36.2 & 13.9 & 336,307 & 86,249 & 64.0 & 3.5 & 2.0 & 25.7 & 1.4 & 3.4 \\
\hline Poor $(29 \%)$ & 14,471 & 3,843 & 36.8 & & 1.5 & 58.7 & 3.0 & 212,527 & 57,024 & 65.0 & 2.8 & 2.4 & 24.0 & 1.0 & 4.7 \\
\hline
\end{tabular}

Notes: *Civil service wages. All estimates are weighted means, with weights inversely proportional to selection probabilities; 'hhinc' is income per household; 'aeqinc' is income per resident adult equivalent: the no of aes per household is defined as (adults plus $0.5 *$ children) ${ }^{\wedge} .5$; 'remit' is remittance income in goods and cash; 'pens' is pensions; 'farm' is sales of agricultural produce plus estimated production for own consumption; 'hhwea' and 'aeqwea' are wealth per household and per adult equivalent; 'hhassts' are household assets; 'fmassts' are inanimate farm assets. Asset valuations are those provided by respondents, except for livestock (valued at prevailing market prices) and land in Limpopo (valued at 1,500 Rand/ha). 
In most of the few cases (mainly in West Africa) where landed rural households are no better off than the landless, it is because the latter have moved from low-productivity farming into local non-farm activities. This is not the case in the Limpopo survey areas, so the lack of surveyed welfare differences between landed and other households within these areas is surprising. A major explanation (Appendix) may be that the penning-up of over 60 per cent of Limpopo's farmland with barely 2 per cent of farms - often in other areas - has led to the pre-emption, by these farms and areas, of the lion's share of irrigation, improved technology and modern inputs. Hence landholding in the exhomelands on average yields little income (while the growth of an African RNFS is hampered by the absence of much local demand for rural non-farm production).

Some support for this is provided by our later disaggregation by region. This shows that for a minority of regionally concentrated non-poor households (in West), the possession of large livestock and inanimate farm assets is important to livelihoods, and strongly correlated with size of landholding (Section III(iv)). That escape from poverty through agriculture in Limpopo is possible may have important implications for the possible benefits to be derived from land reform, and from research or infrastructure provision that raises the productivity of smallholders' land and other farm assets.

If landlessness as such is not responsible for poverty on average, what is? Are Limpopo's poor special in terms of income structure or asset structure (Table 2)? The poor derive a similar mean share of income from wages as the non-poor, ${ }^{28}$ but a larger share from pensions and a smaller share from migrant remittances. As will be shown, these averages are a manifestation of (a) sharp specialisation by income-source among households in general; and (b) relatively high and relatively low poverty incidence, respectively, among households mainly dependent on pensions and on migrancy. ${ }^{29}$ On assets, Table 2 shows that poor households on average hold low shares in productive non-land farm assets, especially large livestock and inanimate farm assets. Ownership of such assets is highly skewed. The Gini of wealth is 0.48 , but the concentration indices for farm assets and largestock are 0.89 and 0.80 respectively. ${ }^{30}$ Only about one household in six has any inanimate farm assets at all, and only one in six has any large livestock; one in sixteen has both, and poverty in this subgroup is essentially zero.

Is it worklessness that explains the bulk of poverty? Our survey indicates extremely high unemployment among working-age persons for rural Limpopo (Table 3). 8 per cent, though not disabled, were 'not seeking work'; we count these 'discouraged workers' as unemployed, as well as those so reporting. Estimated unemployment is then 60 per cent for males and 70 per cent for males and females together. An estimated 60 per cent of households have nobody of working age employed (we call such households 'workless', not quite accurately). Given the high mean share of wages in income and the low salience of farm incomes, one might assume that poverty would be concentrated in workless households; its incidence is indeed somewhat higher in them, although not very significantly (23 per cent compared to 16 per cent in working households, $p 1 / 40.14$ ). Yet income per adult equivalent in workless households is, on average, no less than in households with one working individual of working age. The implication, examined below, is that mean income shares are 
obscuring a specialisation among households, whereby worklessness (or wagelessness) is associated with higher incomes from remittances and/or pensions.

\section{Income-Source Specialisation of Livelihoods: A Three-Way Split}

We have shown the sharp contrast between Limpopo and Rajasthan in terms of average income measures of rural dependency: 43 per cent vs. 83 per cent for the local income share, and 29 per cent vs. 83 per cent for the local income share excluding civil service income. Another dimension of high rural dependency in Limpopo is a remarkable specialisation of households by income source. If shares of local, remittance and pension incomes of, respectively, 43 per cent, 39 per cent and 18 per cent reflected household diversification and risk-reduction in face of weak local income prospects, many households would live on a mix of income sources corresponding very roughly to the aggregate shares; few would be 'specialised' to the extent of deriving over half their income from just one of these sources. Yet, on this definition, an estimated 98 per cent of the households are specialised: 39 per cent are factor-reliant (FR), averaging 93 per cent of income local; 32 per cent are migrancy-dependent (MD), averaging 84 per cent of income from remittances; and 27 per cent of households are pension-dependent (PD), averaging 79 per cent of income from pensions. The demographics, while of interest, do not explain dependency: proportions of working-age persons in $\mathrm{PD}, \mathrm{MD}$ and $\mathrm{FR}$ households differ little $(0.49,0.52$ and 0.52 respectively: Table 4$) .{ }^{31}$

This striking distinctness, or 'three-way-split', of households may account for some earlier findings. If high non-local incomes were associated with low local incomes (and high unemployment), then a weak or absent link between poverty and worklessness or landlessness might result. ${ }^{32}$ Our Limpopo data exhibit these associations. Estimated rank correlation coefficients between 'local' income (farm income plus wages) and pensions and remittances respectively are minus $0.297\left(\mathrm{p}^{1 / 4} 0.000\right)$ and minus $0.308\left(\mathrm{p}^{1 / 4} 0.000\right) .{ }^{33}$

For a further test, we divided the sample according to whether pension and remittance income alone were sufficient to push the household above the poverty line; about half the sample are 'externally subsistent' on this definition. Local income in externally subsistent households averages only 18 per cent of local income in other households (76 per cent in Rajasthan, where 11 per cent of households are externally subsistent).

So the negative association between external and local incomes is strong in Limpopo. To test the association between external income sources and unemployment - while avoiding the selection bias that automatically links FRhouseholds with lower unemployment - we reclassified households, not as FRPD-MD, but according to whether they had any pension income (43 per cent) or any remittance income (45 per cent; 18 per cent have both). In line with the income correlations, the male unemployment rates in pension-receiving and remittance-receiving households are similar, in the range 75-80 per cent (Table 3 ), against 34 per cent in the 30 per cent of households with no such external income.$^{34}$ This association is robust to the inclusion of controls, as shown in the probit analysis (Table 5) of individual employment status on education status, region and whether or not the household is in receipt of pension or remittance income. 
Table 3. Working age residents in Limpopo sample

\begin{tabular}{|c|c|c|c|c|c|c|c|c|c|c|c|c|}
\hline & \multicolumn{3}{|c|}{ Hh has no pen or remit inc } & \multicolumn{3}{|c|}{ Hh has pension income } & \multicolumn{3}{|c|}{ Hh has remittance income } & \multicolumn{2}{|c|}{ All households } & \multirow[b]{2}{*}{ se } \\
\hline & Freq. & Per cent & $\mathrm{se}$ & Freq. & Per cent & $\mathrm{se}$ & Freq. & Per cent & $\mathrm{se}$ & Freq & Per cent & \\
\hline \multicolumn{13}{|l|}{ Males and females } \\
\hline $\begin{array}{l}\text { Missina/other } \\
\text { Housewife } \\
\text { Studying } \\
\text { Unemploved } \\
\text { Emploved } \\
\text { Retired/disabled } \\
\text { Total }\end{array}$ & $\begin{array}{r}9 \\
42 \\
133 \\
184 \\
179 \\
7 \\
554\end{array}$ & $\begin{array}{c}1.3 \\
11.6 \\
24.66 \\
32.14 \\
29.45 \\
0.85 \\
100\end{array}$ & $\begin{array}{l}0.54 \\
1.89 \\
2.42 \\
2.57 \\
2.38 \\
0.41\end{array}$ & $\begin{array}{r}24 \\
37 \\
182 \\
290 \\
80 \\
85 \\
698\end{array}$ & $\begin{array}{c}1.52 \\
8.15 \\
25.11 \\
43.40 \\
8.42 \\
13.39 \\
100\end{array}$ & $\begin{array}{c}0.4 \\
1.65 \\
2.18 \\
2.52 \\
1.14 \\
1.8\end{array}$ & $\begin{array}{r}16 \\
41 \\
210 \\
272 \\
84 \\
49 \\
672\end{array}$ & $\begin{array}{c}1.69 \\
11.44 \\
28.80 \\
39.84 \\
9.67 \\
8.56 \\
100\end{array}$ & $\begin{array}{l}0.5 \\
2.03 \\
2.34 \\
2.54 \\
1.29 \\
1.64\end{array}$ & $\begin{array}{r}41 \\
102 \\
450 \\
642 \\
327 \\
104 \\
1666\end{array}$ & $\begin{array}{c}1.44 \\
10.07 \\
26.63 \\
38.63 \\
16.32 \\
6.91 \\
100\end{array}$ & $\begin{array}{l}0.29 \\
1.14 \\
1.46 \\
1.59 \\
1.06 \\
0.89\end{array}$ \\
\hline \multicolumn{13}{|l|}{ Males } \\
\hline $\begin{array}{l}\text { Missing/other } \\
\text { Housewife } \\
\text { Studying } \\
\text { Unemployed } \\
\text { Employed } \\
\text { Retired/disabled } \\
\text { Total }\end{array}$ & $\begin{array}{r}3 \\
0 \\
57 \\
62 \\
121 \\
4 \\
247\end{array}$ & $\begin{array}{c}1.74 \\
0.00 \\
25.23 \\
24.09 \\
47.26 \\
1.70 \\
100\end{array}$ & $\begin{array}{l}1.13 \\
\\
3.71 \\
3.6 \\
4.09 \\
0.97\end{array}$ & $\begin{array}{r}12 \\
1 \\
92 \\
117 \\
41 \\
22 \\
285\end{array}$ & $\begin{array}{l}1.98 \\
1.46 \\
32.64 \\
42.47 \\
10.99 \\
10.47 \\
100\end{array}$ & $\begin{array}{l}0.74 \\
1.44 \\
3.78 \\
3.97 \\
2.1 \\
2.8\end{array}$ & $\begin{array}{r}10 \\
0 \\
90 \\
95 \\
31 \\
10 \\
236\end{array}$ & $\begin{array}{c}3.21 \\
0.00 \\
40.30 \\
37.01 \\
11.10 \\
8.37 \\
100\end{array}$ & $\begin{array}{l}1.24 \\
4.58 \\
4.33 \\
2.44 \\
3.39\end{array}$ & $\begin{array}{r}18 \\
1 \\
203 \\
235 \\
185 \\
29 \\
671\end{array}$ & $\begin{array}{c}1.88 \\
0.67 \\
32.43 \\
35.01 \\
23.85 \\
6.16 \\
100\end{array}$ & $\begin{array}{l}0.58 \\
0.67 \\
2.53 \\
2.5 \\
2.03 \\
1.51\end{array}$ \\
\hline Male unemployment ra & & $33.80 \%$ & & & $79.40 \%$ & & & $77.00 \%$ & & & $59.50 \%$ & \\
\hline
\end{tabular}


Table 4. Three way split: demography, income and assets

Demography

\begin{tabular}{|c|c|c|c|c|c|c|}
\hline & Shares & Residents & $\mathrm{AEQ}$ & Wkage & WkageM & WkageF \\
\hline$\overline{\mathrm{All}}$ & $100.0 \%$ & $6.29(.15)$ & $4.17(.09)$ & $3.19(.09)$ & $1.26(.06)$ & $1.93(.06)$ \\
\hline $\begin{array}{l}\text { FR } \\
\text { PD } \\
\text { MD } \\
\text { Other }\end{array}$ & $\begin{array}{r}38.5 \% \\
26.8 \% \\
32.3 \% \\
2.3 \%\end{array}$ & $\begin{array}{l}6.80(.22) \\
6.80(.34) \\
5.30(.22)\end{array}$ & $\begin{array}{l}4.42(.13) \\
4.58(.18) \\
3.55(.13)\end{array}$ & $\begin{array}{l}3.53(.13) \\
3.30(.19) \\
2.73(.15)\end{array}$ & $\begin{array}{l}1.51(.09) \\
1.41(.16) \\
0.88(.11)\end{array}$ & $\begin{array}{l}2.02(.08) \\
1.88(.14) \\
1.85(.10)\end{array}$ \\
\hline Frpoor & $28.8 \%$ & $7.46(.40)$ & $4.76(.22)$ & $3.73(.23)$ & $1.32(.20)$ & $2.41(.15)$ \\
\hline \multicolumn{7}{|c|}{ Incomes } \\
\hline & Mean/HH & Mean/AEQ & \%Pens & $\%$ Remit & $\%$ Wages & \%Fan \\
\hline
\end{tabular}


For example, a working-age male in a pension-receiving household has an employment probability 34.4 per cent lower than in a non-pension-receiving household in the same region and similar in education. The corresponding figure for a member of a remittance-receiving household is 28.5 per cent. Note also that (a) while higher education substantially raises employment chances, secondary education reduces them; and (b) living in West is much better for employment prospects than living in South or Central.

Why are resident adult unemployment rates so much higher in pension/remittance receiving households? Suppose first that resident household composition is exogenous (so that unemployment does not make the unemployed likelier to shift into such households). Then an external income source may reduce the incentive for residents to seek work in either household type, increasing their unemployment rate (recall that we count able-bodied adult non-work-seekers as unemployed, 'discouraged workers'). But why, then, are recipients of pensions and remittances more willing to share income with unemployed residents than are recipients of local factor incomes? For households reliant on remittances, migrancy may be cyclical, so that household members take turns to migrate for work. That apart, if the relatively competent (and educated) tend to migrate, then those left behind are more likely to be unable to find work even if they are motivated to do so. This still leaves the

Table 5. Male employment and non-local household incomes

\begin{tabular}{lclc}
\hline & $\begin{array}{c}\text { Marginal effects } \\
\text { (\%: s.e in brackets) }\end{array}$ & p-values & $\begin{array}{c}\text { Means of } \\
\text { regressors (\%) }\end{array}$ \\
\hline Highest education: & $-0.9(1.0)$ & 0.371 & \\
Primary & $-9.3(0.5)$ & 0 & 93.7 \\
Secondary & $25.2(1.0)$ & 0 & 64.4 \\
Higher & $-34.4(0.4)$ & 0 & 6.6 \\
Pension-recipient hh & $-28.5(0.4)$ & 0 & 41.4 \\
Remittance-recipient hh & $-21.2(0.7)$ & 0 & 27.9 \\
Resident of South & $-12.0(0.7)$ & 0 & 16.4 \\
Resident of Central & & & 68.5 \\
& & & \\
Pseudo R-sq = 15.7\% & & & \\
\hline
\end{tabular}

question of why pensioners are willing to share income with fellow-adults with unemployment rates so far above those in households receiving neither pensions nor remittances. Now allow for endogeneity in household composition - an impact of income types upon decisions about household formation, modification and destruction. Households unable to provide a minimum of subsistence to their members must collapse; conversely working-age individuals, especially if unemployed, may try (perhaps successfully) to attach themselves to viable households, including those dependent on non-local income. Perhaps, especially in PD households, such attachments involve an element of coercion.

What do we learn about rural dependency from the mean characteristics of the dependent households of each type (Table 4)? There are significant differences in income per adult equivalent among the three groups. MDs are 60 per cent 
better off on average than FRs, who are themselves twice as well off as PDs. Poverty incidence (only 6 per cent for MD households) is a little higher for FRs than for PDs, 29 per cent vs. 26 per cent - and FRs' mean poverty depth is also far higher, despite their much higher mean income than PDs. This reflects much higher income inequality among FR households than among PD households, as would be expected (Ginis in Table 4). However, we do not find significant mean wealth differences among the groups. As far as wealth shares are concerned, there is a hint that farm assets (for FR households) and largestock (for FR and PD households) may be associated with absence of poverty. ${ }^{35}$ However, this does not benefit many households, since holdings of both these assets are highly concentrated. It seems that such limited degree of household 'escape' from rural dependency to factor reliance as is possible without land redistribution in Limpopo (a) brings more productive (but riskier?) wealth, not more wealth; (b) raises mean income and cuts poverty, but leaves a group of very poor households behind.

\section{Regional Variations: Agriculture and Livelihoods in West}

Our survey data (Table 6) reveal significant regional variations, especially between West and the other two regions. In short, West is the most prosperous region: poverty incidence is about half that in the other two regions, and unemployment is markedly lower. ${ }^{36}$ Only in West does agriculture account for a substantial fraction of income, both through own-farm production and agricultural wages, and only in West are there important holdings of large livestock and inanimate farm assets. Households that own both of these assets do well. To a considerable extent, it is more widespread access to higher local factor incomes from farming that makes African households somewhat better off in West than elsewhere in Limpopo.

As regards the comparative importance of agriculture to income in the three regions, adding own-farm income to agricultural wages shows that agriculture in Central and South accounts for no more than 3 per cent of income, but 32 per cent in West, of which about a third is own-farm income. Agriculture accounts for 5 per cent of employment (including self-employment) in Central, 14 per cent in South, and 52 per cent in West. In West (a) wider access by Africans to small, family-labour intensive holdings offers prospects of higher, more diffused ownfarm income; (b) white-owned land used for game and beef ranches, and borehole-irrigated maize and potato production - even if not always near the survey areas - offers better chances 
Table 6. Regional disparities in Limpopo

\begin{tabular}{lccc}
\hline & Central & South & West \\
\hline No of hhs & 128 & 244 & 121 \\
Income & & & \\
HH income (Rand) & $13,401(932)$ & $19,900(1893)$ & $26,784(3036)$ \\
AEQ income (Rand) & $3,838(401)$ & $5,727(567)$ & $6,617(727)$ \\
Povertv & $22.50 \%$ & $21.10 \%$ & $11.10 \%$ \\
\% waqes & $41.90 \%$ & $37.10 \%$ & $46.10 \%$ \\
of which, agriculture & $0.40 \%$ & $0.40 \%$ & $19.80 \%$ \\
of which, civil service & $26.10 \%$ & $14.99 \%$ & $0.00 \%$ \\
$\%$ pens & $31.40 \%$ & $16.50 \%$ & $12.90 \%$ \\
$\%$ farm & $2.60 \%$ & $2.80 \%$ & $12.80 \%$ \\
$\%$ remit & $24.10 \%$ & $43.60 \%$ & $28.20 \%$ \\
$\%$ local, non-civil-service* & $18.40 \%$ & $24.91 \%$ & $58.90 \%$ \\
Wealth & & & \\
HH wealth & $72373(8673)$ & $45061(3340)$ & $80126(7410)$ \\
AEQ wealth & $21137(3696)$ & $12943(1251)$ & $20063(2024)$ \\
Land & & & \\
Prop. landed & 0.56 & 0.52 & 0.91 \\
Mean landholding (landed) & $2.52(.39)$ & $3.08(.18)$ & $2.27(.09)$ \\
Land Gini (landed) & $0.56(.020)$ & $0.29(.019)$ & $0.23(.014)$ \\
Three-way split & & & \\
FR & 30.6 & 39.8 & 43.0 \\
PD & 44.1 & 24.8 & 11.7 \\
MD & 25.2 & 33.6 & 35.6 \\
Mixed-source & 0.0 & 1.8 & 9.7 \\
Farming assets & & & \\
\% with largestock & 12.5 & 13.7 & 33.5 \\
$\%$ with inanimate fm. & 2.3 & 11.4 & 80.0 \\
$\%$ with both fm. asset types & 2.3 & 4.0 & 30.2 \\
Unemployment & & & \\
All & $77.3 \%$ & $71.8 \%$ & $60.4 \%$ \\
Men & $69.3 \%$ & $59.0 \%$ & $50.9 \%$ \\
\hline
\end{tabular}

Notes: *share of farming plus non-civil-service wages; estimated standard errors in brackets.

Abbreviations as in Table 4.

for African farm wage income than in other regions, though less than would be the case with smaller-scale farming of this land.

So agriculture is important to livelihoods in West through both own-farm income and wages. The special nature of West is also revealed in asset structures. West has no advantage over other regions in cropland per average landed household, but (as in Rajasthan) over 90 per cent of households have some cropland; in South and Central the proportion is just over half. Among the landed, cropland is somewhat more equal in West than in South, and much more than in Central; and ownership of livestock and other farm assets is much greater in West than in South or Central. Hence a much larger proportion of households has modest but significant cropland in West: 87 per cent of landed households ( 80 per cent of all households) there have between one and four hectares, as against only 51 per cent ( 27 per cent) elsewhere. Landedness as 
such has been shown to have little direct effect on income at household level, but we can discern an indirect effect through other farm assets, especially inanimate farm assets and large livestock. Holdings of these two types of asset are highly skewed and highly correlated (Spearman rank correlation coefficient $1 / 40.3845, p 1 / 40.0000$ ). Outside West, relatively few households report holding any assets in each of these categories (Table 6). As for holders of assets in both categories, they comprise only 2.3 per cent of households in Central, 4.0 per cent in South and 30.2 per cent in West. The chance of a household having both largestock and inanimate farm assets is strongly related to landholding: virtually no households with less than 1 ha are in this category. ${ }^{37}$ This category of households does very well as regards both income and poverty risk: average income is double that earned in other households and poverty incidence is virtually zero. ${ }^{38}$

What of escape from rural dependency through RNF incomes? We cannot measure the extent to which these in West are underpinned by demand from agricultural incomes, but virtually all non-agricultural local wages in this region are generated in industry and services - in Central and South, 62 per cent and 40 per cent respectively of wages derive from civil service employment. ${ }^{39}$ Hence, despite the high share of income deriving from agriculture in West, the share of income deriving from industry plus service-sector wages is higher than in Central or South (26 per cent compared to 16 per cent and 22 per cent). Total income from local, non-civil-service activity accounts for 59 per cent of total income in West (Central 18 per cent, South 25 per cent, 83 per cent in Rajasthan).

In sum, rural dependency in West, though substantial, is lower than in Central and South. 47 per cent of households are MD or PD households (69 per cent in Central and South; 11 per cent in Rajasthan). West represents, in some senses, a bridge between the rest of Limpopo's experience and that of Rajasthan, being intermediate in both the spread of farmland, and reliance on local income sources. This suggests that, with agricultural development and land redistribution, rural dependency may be reversible elsewhere in the African areas of South Africa. However, these special features of West (and the hopes they engender) should not be overstated. African farmland, though more widely spread than in other areas, remains, even in West, much less (and worse) than white-owned farmland, and largely without water control or modern inputs (in sharp contrast to Rajasthan). Even in West, African farming accounts for only 13 per cent of village income. White farmland, while providing some wage income, is generally farmed in large and capital-intensive units. Much remains to be done before African households in rural South Africa can escape rural dependency.

\section{Summary and Policy Implications}

Cross-sections of developing and transitional countries show a very strong association between land inequality and agricultural workforce share, given GNP/ capita. Historical evidence of dramatic land concentration in early development suggests that this may reflect a causal process in individual countries, whereby land grabs have led to premature deagriculturalisation. The Limpopo ex-homeland survey illustrates the impact on rural livelihoods. Shares 
of income and assets associated with agriculture are very low (8 per cent and 22 per cent); half the households derive less than one-fifth of income from any local sources; 59 per cent of households 'specialize' in dependency on either migrant or pension income; male unemployment is also 59 per cent, and much higher in the 'specialist' households; farmland-per-household is as much as 2.8 hectares among the 57 per cent with cropland, but the landed are no better off than the landless in terms of poverty risk or income. Such outcomes are less marked in West region (with more widely spread farmland), and are almost absent in a parallel survey in Rajasthan.

What implications have these findings for policy change in rural South Africa? Experience in many countries confirms the feasibility of poverty reduction via land redistribution, and of subsequent growth in farm output and employment. About three in four of South Africa's dollar-poor are rural, almost all being Africans in former 'homelands' such as our survey area; rural poverty incidence is highest in Limpopo and the Eastern Cape provinces, where 44 per cent of South Africa's poor reside (Development Bank of Southern Africa, 2000). Given the many unemployed rural poor, is land redistribution a useful tool of poverty reduction, as well as of farm efficiency?

Consensual transfer of one-third of commercial farmland to poor Africans was part of the African National Congress's manifesto in 1994. Some efforts were made in pilots, but usually with scanty supporting inputs or services, and focusing on land for welfare and housing, rather than for smallholder farming. Although the World Bank had made clear its support, and potential financing role, for wide-scale, consensual land redistribution (Van Zyl et al., 1996), the government did not implement this widely or very effectively. Still:

...a survey of about 1200 beneficiaries [shows that, though initial land reform] has not lived up to the quantitative goals set, [it] did successfully target the poor [and] led to a significant number of economically successful projects [that] have involved significantly larger shares of poor people than less viable projects, suggesting that increased access to productive assets could be an important path to poverty reduction .... Suitably adapted land reform could play an important part in restructuring South Africa's rural sector. (Deininger and May, 2000, Summary Findings)

However, subsequently, the government largely replaced that approach by efforts to individualise communal tenure; to broaden ownership of white farms through 'equity sharing'; and, above all, to obtain voluntary transfer of some white-owned farmland into middle-to-large African commercial farms (Wegerif, 2004). Such a transfer will not achieve the full gains to the poor, and reductions in dependency and unemployment, that appear, from cross-sections, to be possible by a shift from larger to smaller farms.

An objection to such a shift (Reardon and Barrett, 2000) is that commercialisation has marginalised small-scale farmers in developing countries, excluding them from the profitable markets of the rich North. However, South Africa's African-run farms are mostly net buyers of food, so that extra output is home-consumed, or cater mainly for local markets, so that problem is less important. Where small farmers do sell for exports and supermarkets, 
intermediation may be needed to facilitate timely collection for processing, crop uniformity, pesticide safety, or labour standards; where this is successfully achieved, including in some African cases (tea in Kenya, cotton in Burkina), smaller farms' advantages resurface. But successful intermediation may not be profitable, and even if it is cannot be taken for granted without public or collective action.

The merits of land redistribution in any specific case cannot be assumed. Can South Africa (or Russia), with farming already settled into severe asset and input inequality, consensually 'undo history' and improve outcomes by reverting to a more equal small-farm model? Will disruption costs, e.g., with capital assets and water systems geared to large-scale farming, be excessive? Can rural people long deprived of land and other relevant resources - and the supply systems that might service these - operate in a small-farm environment (however attractive in cross-section), or is it true that peasant sectors 'when once destroyed, can never be supplied' (Goldsmith, 1770)?

Such questions require assessment of alternatives. Starting from South Africa's very high (and genuine) unemployment - with its consequences for failed townward migration, family breakdown and crime - can mass poverty (and slow growth) be tackled without substantial, productive absorption of labour in small-scale agriculture, and in a rural nonfarm sector linked to its growth? Prospects for labour absorption in the urban non-farm sector appear limited, given the weak growth, high capital-intensity and low competitiveness of modern manufacturing in South Africa, as compared say to Malaysia after its more normal deagriculturalisation. Conversely the policy of getting land and other farm resources to an underemployed, but far from destroyed, peasantry appears to have proved feasible in a range of cases, both in Latin America and in transition economies (China 1977-84, Vietnam 1988-93, Albania, Armenia and Romania).

Economic development paths almost always involve deagriculturalisation. Normally, this is of a 'mature' agricultural sector, following a spurt of labourintensive agricultural growth, mainly on smallholdings. Changing demand patterns (Engel's Law) and voluntary savings transfers out of agriculture then make it attractive and feasible for both migrant workers and entrepreneurs to shift to modernising industry and services. A different path is premature deagriculturalisation. A farm sector, made highly unequal, provides little productive work on its large and capital-intensive farms, while its smallholdings lack resources for growth (in South Africa water control, research, and marketing systems). Labour floods from such a sector to the towns, but the sources of investment finance, adequate to employ it, are not clear. Our findings support much development theory and empirical work indicating that there is seldom an obvious alternative, if seeking broad-based growth, to a path through small-scale agriculture and related RNF activity. The experience of Rajasthan - and to a lesser extent of West region in Limpopo - suggests that such a path is feasible. 
1. Among unwanted side-effects, deficient rural earning opportunities have stimulated urban slum growth (and associated unemployment and crime) - but not emigration. South Africa is a net immigrant country, partly because of sluggish agricultural earning opportunities elsewhere in Africa. Recent sharp falls in agricultural employment suggest that rural dependency, although a long-run effect of land distributions associated with apartheid, may have intensified since its demise. Total paid farm employment fell only slowly in 1985-93 (from 1.32m to 1.14m). However, from 1994 to 2001 total employment in agriculture, fisheries and forestry - including selfemployment - dropped by some 66 per cent (Vink and Kirsten, 1999).

2. In South Africa, 15 per cent of farmland is divided among about a million mainly African farm operators (mostly part time), leaving 85 per cent of land with some 60,000 white commercial farmers outside the surveyed (smallholding) areas (NDA 2001; Department of Land Affairs, 2002). About 2 per cent of land in large whiteowned farms in 1994 had been redistributed up to the end of 2001, only about 5 per cent of it through DLA projects and the rest through private transactions.

3. This paper derives from EU-supported research on the impact - on fertility, migration, and thus and otherwise agro-environmental sustainability - of land and asset size and distribution in selected rural drylands of Limpopo province, Rajasthan, and Botswana.

4. Such healthy RNF growth may also be happening in parts of Sub-Saharan Africa (Reardon, 1997; Bryceson, 2000; Reardon and Barrett, 2000) where land is less unequal than in Limpopo.

5. Bryceson defines 'deagrarianisation' 'as a process of occupational adjustment, income-earning reorientation, social identification and spatial relocation of rural dwellers away from strictly agricultural-based modes of livelihood', whereas "depeasantisation" represents a specific form of deagrarianisation in which peasantries lose their economic capacity and social coherence, and shrink in size', Bryceson (2000: 1-2).

6. A specific-factors model, with agricultural capital unimportant, becomes less plausible as development proceeds. Empirical $\mathrm{H}-\mathrm{O}$ models explaining agriculture's trade share include Leamer (1984), Lal and Myint (1996), Wood (1994).

7. One imperfection is insufficient: e.g., non-tradability of (family) labour, gives heterogeneity in farm size - large families have large farms - but all physical ratios are scale-invariant.

8. See above sources and Binswanger et al. (1995). Booth (2002: 85) shows 'postGreen-Revolution' Indonesian farm income/ha. steadily falling from Rp718,000 on holdings below 0.1 ha to Rp23,000 above 4.5 ha. Land productivity falls less sharply than the labour-land ratio, since labour productivity rises.

9. However, some endogenous differences - smaller, labour-intensive farms doing more to upgrade their land - are implied by higher yields on smaller holdings on land of similar region, type or quality (Berry and Cline, 1979; Lipton, 1993; Binswanger et al., 1995).

10. By symmetry, the release of labour from agriculture might raise non-agricultural output by lowering wages. Such effects may be assumed to be small in labour-surplus economies.

11. We include all countries with available data. To allow for variations in country size we weight observations by the square root of total workforce. If countries may be viewed as aggregates of independent regions, then the error variance decreases with country size suggesting this initial heteroscedasticity correction (Blanchet, 1988).

12. These results might have been distorted by cross-country variation in the share of extractive industry in non-agricultural GDP, but this variable had no statistical significance when included in our equations.

13. The unweighted means are 0.82 and 0.56 .

14. See, for example, Bennett and Powell (1999), Reynolds (2003).

15. The proportion of households selected differed across villages. Unless otherwise stated, all statistical calculations use weights inversely proportional to the probability of a given household having been selected.

16. We depart in one respect from the administrative regional sub-division: on 
geographical and agro-ecological grounds, Zebediela sub-district is included in our 'South'.

17. African tenancy had little impact on land access in Limpopo. On white farms it was prohibited, though this did not prevent some 'labour tenancy'. In African areas tenancy is minimal, due to customary law.

18. At PPP exchange rates, sample income per adult equivalent is 50 per cent higher in Limpopo than in Rajasthan. Using the official rural poverty line in Rajasthan, household poverty incidences are respectively 20 per cent and 29 per cent.

19. Henceforth we omit the qualifiers; our surveys are restricted to rural dryland areas in both cases and additionally to former homeland areas in Limpopo.

20. Our 'income' measure is imperfect. We estimate production for own-consumption using household reports of the fraction of needs so met. Farm income is defined as production for own-consumption plus sales, i.e., without subtracting input purchases, on which data were unavailable.

21. This risks double-counting if smallholders earn wages on each other's farms (rather than on large commercial farms, as happens to an unknown extent in Limpopo), so the totals given are likely to be overestimates.

22. Estimated employment in agriculture, including self-employment, is only 22 per cent of all rural employment in Limpopo (about 44 per cent in Rajasthan). The employment numbers, estimated from individuals who reported a sector of work, must be treated with caution; some individuals may have failed to report a sector of work, even though they work on their own land.

23. Access to common grazing land is not taken into account in our measure of landholding. However, absence of cropland is strongly associated with lack of livestock, and therefore with lack of benefits from common grazing.

24. The null of equality of income per household between landed and landless households cannot be rejected in Limpopo, but is rejected in Rajasthan at the 1 per cent level.

25. The asset value and share estimates must be treated with caution; see Table 2, note (c). In the Limpopo ex-homeland area, land is rarely traded; the assumed value (1500 Rand/ha) is based on market prices for comparable land in adjacent commercial farming areas (Department of Land Affairs, 2002a). Livestock aside, other asset valuations in Rajasthan and Limpopo are by household respondents.

26. Our poverty line is the rural expenditure per person needed in Rajasthan to achieve the Indian poverty line ( $\mathrm{Dr} \mathrm{S}$. Sharma, Delhi School of Economics, personal communication, using 1999-2000 round, National Sample Survey). We converted this into Rand using the PPP exchange rate. In both Rajasthan and Limpopo we used sample mean adult equivalents per household to convert the per person line into a per-aeq line, which for Limpopo is 1594 Rand/aeq/yr. Lacking expenditure data for Limpopo we had to ignore below-poverty-line differences between expenditure and income.

27. In Rajasthan too, there is a strong negative association between poverty risk and landholding.

28. Compare Rajasthan, where the poor, of whom only 7 per cent are landless, derive a high share of income from farming and a correspondingly low share from wages.

29. Depth of poverty, however, is significantly lower for pension-dependent households (defined below; estimated mean income per adult equivalent among the poor is 23 per cent below the poverty line) than for others (around 50 per cent).

30. The concentration index is analogous to the Gini. For instance the associated Lorenz curve for, say, largestock has households ordered by wealth on the x-axis and the cumulative share of total largestock on the $y$-axis.

31. As for gender, the female/male ratio is 2.10 in MD households as against 1.34 for FRs. However, this is probably an effect of selective male migration, not a cause of MD status.

32. The weak association may also be partly due to offsetting effects of much higher unemployment among both households with pensions (which have high poverty incidence) and with migrancy income (which have little poverty) than among households with neither. 
33. A rank correlation test is more appropriate than a linear one given the highly bunched nature of the data (many zeroes). The correlation for local income against (pensions plus remittances) was -0.44 ( $\mathrm{p}^{1 / 4}$ 0.000). The same tests on our Rajasthan sample give a very small positive, insignificant correlation between local income and pensions and small negative correlations between local income and, respectively, remittances (rho $1 / 4$ 70.12, $\mathrm{p}^{1 / 4}$.003) and pensions (rho $1 / 4$ 70.10, p 1/4 0.02)

34. As one would expect (because the definitions of PD and MD select households that have little local income and accordingly low employment of residents), the male unemployment rates in the PD and MD households that together account for 59 per cent of all households are even higher, at 93 per cent and 92 per cent.

35. The poor have a higher share in dwellings, consistent with the presence of capital market imperfections that may prevent even the landed poor from escaping poverty through more effective land use.

36. The 1995 Central Statistical Services's Household Survey confirms this picture (Gyekye and Akinloye, 2001)

37. Both living in West and landholding are strongly associated with both the possession of inanimate farm assets and livestock and the quantity possessed.

38. Point estimate 1.6 per cent (two sample households).

39. Including teachers but not parastatal employment. 


\section{References}

Bennett, T. W. and Powell, C. H. (1999) Aboriginal title in South Africa revisited, South African Journal of Human Rights, 15(4), pp. 449-485.

Bell, C., Hazell, P. and Slade, R. (1982) Project Evaluation in Regional Perspective (Baltimore: Johns Hopkins).

Binswanger, H., Deininger, K. and Feder, G. (1995) Power, distortions, revolt and reform in agricultural land relations in: J. Behrman and T. N. Srinivasan (eds), Handbook of Development Economics: vol. IIIB (Amsterdam: North Holland).

Berry, R. and Cline, W. (1979) Agrarian Structure and Productivity in Developing Countries (Baltimore: Johns Hopkins).

Blanchet, D. (1991) Estimating the relationship between population growth and aggregate economic growth in LDCs: methodological problems, in: Consequences of Rapid Population Growth in Developing Countries Proceedings of the United Nations Expert Group Meeting, New York, 23-26 August 1988 (New York: Taylor \& Francis).

Booth, A. (2002) The changing role of non-farm activities in agricultural households in Indonesia: some insights from the agricultural censuses, Bulletin of Indonesian Economic Studies, 38, pp. 179-200.

Booth, A. and Sundrum, R. (1984) Labour Absorption in Agriculture (Delhi: Oxford University Press).

Bryceson, D. (2000) Sustaining Rural Livelihoods in Sub-Saharan Africa: Sustaining What and For How Long? (Manchester: University of Manchester).

Bryceson, D. and Jamal, V. (eds) (1997) Farewell to Farms: De-agrarianisation and Employment in Africa (Ashgate: Avebury).

Byrd, W. A. and Qingsong, L. (1990) China's Rural Industry (Oxford: World Bank Research Publications).

Deininger, K. and May, J. (2000) Can There Be Growth with Equity? An Initial Assessment of Land Reform in South Africa: World Bank Policy Research Working Paper 2451 (Washington, DC: World Bank).

Deininger, K. and Olinto, P. (2000) Asset Distribution, Inequality and Growth (Washington, DC: World Bank).

Department of Land Affairs (2002) accessed at: http://land.pwv.gov.za/publications/parliamentary_questions/nat_assembly.htm

Department of Land Affairs (2002a) Land price database, accessed at: http://land.pwv.gov.za/redistribution/newpage7.htm

Development Bank of Southern Africa (2000) Development Report 2000, Building Developmental Local Government, Development Bank of Southern Africa, Halfway House, South Africa.

Eswaran, M. and Kotwal, A (1986) Access to capital and agrarian production organisation, Economic Journal, 96, pp. 482-98.

Food and Agriculture Organisation (FAO) (2001) Supplement to the Report on the 1990 World Census of Agriculture (Rome, FAO).

Goldsmith, O. (1770) The Deserted Village (London: The Goldsmith Press Ltd).

Gyekye, A. B. and Akinloye, O. (2001) Analysis of poverty in the Northern Province of South Africa: implications for empowerment policy, Conference of the Economic Society of South Africa, Johannesburg.

Harriss, B. (1987) Regional growth linkages from agriculture: discussion, Journal of Development Studies, 23, pp. 275-89.

Hazell, P. and Roell, A. (1983) Rural Growth Linkages: Household Expenditure Patterns in Malaysia and Nigeria (Washington, DC: International Food Policy Research Institute).

Hazell, P. and Ramasamy, C. (1991) The Green Revolution Reconsidered: The Impact of High-Yielding Varieties in South India (Baltimore: Johns Hopkins).

Heltberg (1998) Rural market imperfections and the farm size-productivity relationship: evidence from Pakistan, World Development, 26, pp. 1807-26. 
International Fund for Rural Development (IFAD) (2001) Rural Poverty Report 2001: The Challenge of Ending Rural Poverty (Oxford: Oxford University Press).

Kirsten, J., Rwelamira, J., Fraser, F. and Makhura, M. (2002) The effect of rural inequality on fertility, migration, environment and thus agricultural sustainability: a case study in the arid and semi-arid areas in Limpopo Province, South Africa, accessed at: www.sussex.ac.uk/Units/PRU/demography.html

Kriedte, P., Medick, H. and Schlumbohm, J. (1981) Industrialization before Industrialization: Rural Industry in the Genesis of Capitalism (Cambridge: Cambridge University Press).

Krugman, P. and Obstfeld, M. (2003) International Economics: Theory and Policy (Addison Wesley: Longman).

Kutcher, G. and Scandizzo, M. (1981) The Agricultural Economy of Northeast Brazil (Baltimore: Johns Hopkins).

Lal, D. and Myint, H. (1996) The Political Economy of Poverty, Equity and Growth: A Comparative Study (Oxford: Clarendon Press).

Leamer, E. (1984) The Sources of International Comparative Advantage (Cambridge, MA: MIT Press).

Lipton, M. (1993) Land reform as continued business: the evidence against stopping, World Development Studies, 21, pp. 641-57.

Mellor, J. (1976) The New Economics of Growth: A Strategy for India and the Developing World (Ithaca: Cornell University Press).

NDA (2001) Abstract of Agricultural Statistics (Pretoria: National Department of Agriculture).

Ogilvie, S. and Cerman, M. (eds) (1996) European Proto-Industrialization (Cambridge: Cambridge University Press).

Ravallion, M. and Sen, B. (1994) How Land-Based Targeting Affects Rural Poverty (Washington, DC: World Bank).

Reardon, T. (1997) Using evidence of household income diversification to inform study of the rural nonfarm labour market in Africa, World Development, 25(5), pp. 735-47.

Reardon, T. and Barrett, C. B. (2000) Agroindustrialization, globalization, and international development: an overview of issues, patterns, and determinants, Agricultural Economics, 23, pp. 195-205.

Reynolds, H. (2003) Killing off the case for terra nullius, The Age, August 23.

Sagar, V. (2002) The effect of inequality on human fertility, migration and agricultural stability: The case of West Indian Drylands: Rajasthan, accessed at: www.sussex.ac.uk/Units/PRU/demography.html

Sen, A. K. (1972) On Economic Inequality. Clarendon Lectures. Oxford University Press.

Vink, N. and Kirsten, J. F. (1999) A descriptive analysis of employment trends in South African agriculture, Agrekon, 38(2), pp. 204-28.

Wegerif, M. (2004) A critical appraisal of South Africa's market-based land reform policy: the case of LRAD in Limpopo. Research report 19, University of the Western Cape School of Government: Programme for Land and Agrarian Studies.

Wood, A. (1994) North-South Trade, Employment and Inequality: Changing Fortunes in a Skill-Driven World (Oxford: Clarendon Press).

van Zyl, J., Kirsten, J. and Binswanger, J. (eds) (1996) Agricultural Land Reform in South Africa: Policies, Markets and Mechanisms (Cape Town: Oxford University Press). 
Appendix

(a) Estimating the Land Gini in Limpopo Province

1. The size distribution of white-owned farms is estimated from Census of Agriculture 1993, page 4, which gives numbers of farms in 14 size categories and allows calculation of mean holding by category. We assume that all farms within each category are equal-sized.

2. We assume one million smallholdings in South Africa. The Census gives white commercial farms 87 per cent of $82.76 \mathrm{~m}$ ha. total farmland. Mean (grazing plus arable) land per smallholding can then be estimated at 12.37 ha.

3. We estimate mean arable smallholding size in Limpopo as 2.85ha. Assuming Limpopo smallholdings representative of national smallholdings, and the grazing-arable ratio constant across Limpopo smallholdings, we scale up the sample holdings by $12.37 / 2.85$ to approximate their size distribution.

4. For total Limpopo smallholdings, we average two estimates: (a) the (Census) rural population of 4.5 million, with our sample estimates for mean household size and proportion of household landless, gives 0.27 million smallholdings; (b) the (Census) 23 per cent of South Africa's rural population in Limpopo, implies 0.23 million smallholdings given (2), if provincial smallholdings are in proportion to population.

5. (3) scaled up by (4) gives an estimate of the size distribution of Limpopo smallholdings. Amalgamation with (1) gives:

\begin{tabular}{lcccc}
\hline & Mean size (hectares) & Number & Total land (million ha) & Gini \\
\hline Commercial farms & 1055.9 & 5,053 & 5.3 & 0.80 \\
Smallholdings & 12.4 & 250,000 & 3.1 & 0.39 \\
& & & & 0.93 \\
Total & 32.9 & 255.053 & 8.4 & 0.93 \\
\hline
\end{tabular}

(b) Equalising land redistribution and farm employment

For non-intersecting Lorenz curves, any reduction in land inequality can be represented as a sequence of transfers of land from larger to smaller holdings (Sen, 1972). Denote land by $N$, labour by $L$ and the average and marginal labour-land ratios by $A(N)$ and $M(N)$. Then $M(N)=A(N)+N^{\prime} A^{\prime}\left(N_{1}\right)$. A small equalizing land transfer from a farm of size $N_{1}$ to a smaller one of size $N_{0}$ raises labour if:

$$
M\left(N_{0}\right)-M\left(N_{1}\right)=\left\{A\left(N_{0}\right)-A\left(N_{1}\right)\right\}+N_{0} A^{\prime}\left(N_{0}\right)-N_{1} A^{\prime}\left(N_{1}\right)>0
$$

If $A^{\prime}(N)<0$, the term in braces, increased employment on the transferred land, is positive. The negative second term, $\mathrm{N}_{0} \mathrm{~A}^{\prime}\left(\mathrm{N}_{0}\right)$, arises from the fall in labourintensity on the smaller farm because of its enlargement, and the positive third term, $-N_{1} \cdot A^{\prime}\left(N_{1}\right)$ from the rise in labour-intensity on the larger farm because of its shrinkage. The bigger the gap in the labour-land ratio between the 'receiving' 
and the 'giving' farms, the larger is the term in braces and the more likely a rise in total employment.

\section{(c) Data sources for Table 1}

Numbers of agricultural and non-agricultural economic actives in 2000: FAOSTAT; PPP GNP/capita (1999): World Bank; share of agriculture in GDP (averaged for 1999, 2000, 2001): World Bank; country coverage: all countries classified in the 2005 WDR as low or middle income, except those with less than 500,000 ha. of agricultural land (Table 1.1 of $F A O(2001)$ ). Land Ginis are taken from FAO (2001) where possible, otherwise Deininger/Olinto(2000), or (if clearly more recent) Table 3.1 in IFAD (2001), page 117. These two sources were mostly in agreement; except for (i) Bangladesh: IFAD's 0.55 for 1981-90 was preferred to DO's 0.42 (equal to IFAD's 1971-80 figure), and (ii) Mexico: DO's 0.61 was preferred to IFAD's 1961-70 figure 
(d) Map

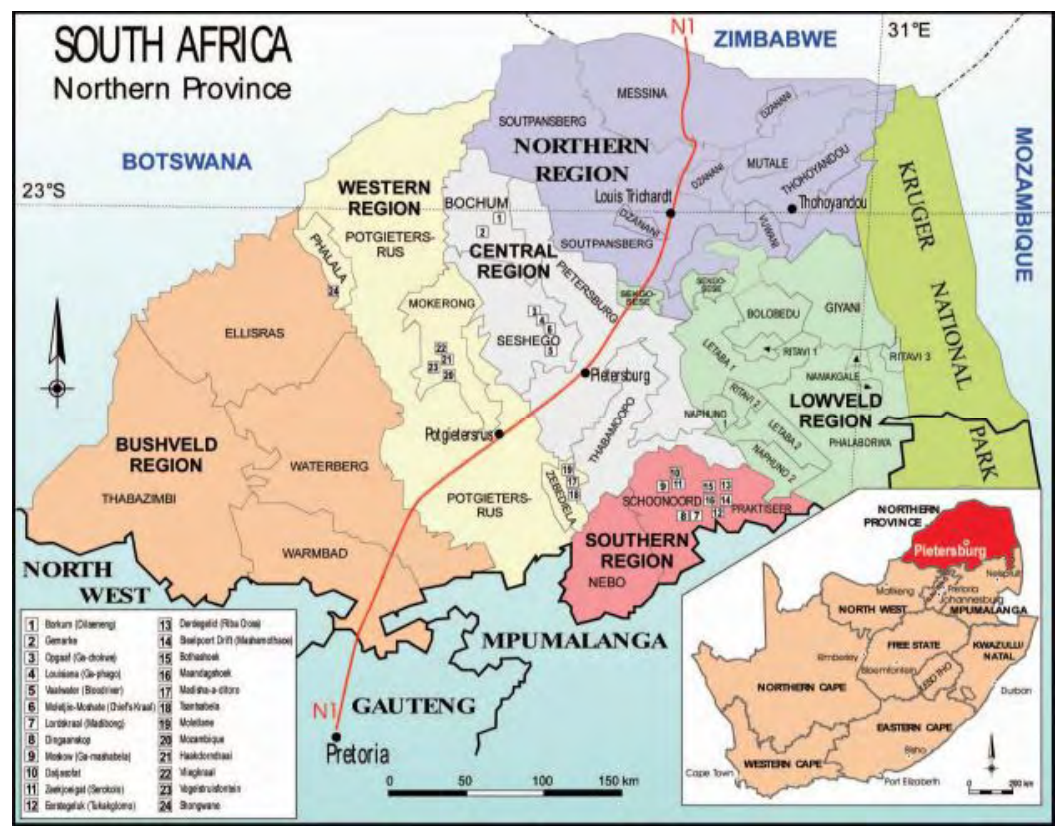

Map 1. The Districts and Sites in the Study Area 